\title{
STUDENTS' AND LECTURERS' PERCEPTIONS OF THE EFFECT OF OPEN-BOOK EXAMINATIONS ON TEACHING AND ASSESSMENT AT DEPARTMENTS OF ACCOUNTANCY AT SOUTH AFRICAN
}

UNIVERSITIES

\section{S. J. Kruger}

School of Accountancy

Stellenbosch University

Stellenbosch, South Africa

e-mail: sjkruger@sun.ac.za

\section{ABSTRACT}

Strong arguments are put forward in literature that teaching methods should be aligned with assessment practices in order to optimise the teaching-learning environment. When the South African Institute of Chartered Accountants changed its initial test of competence examination (ITC) from a closed-book to an open-book format, accredited universities changed their assessment accordingly. This article investigates how students and lecturers perceive the changes made to teaching and assessment after the introduction of open-book assessment. A survey was performed among prospective chartered accountants preparing for the ITC. These students were mostly assessed through closed-book examinations in their graduate studies, but were assessed using open-book examinations in their final year. The views of students and lecturers in certain universities' departments of accountancy were compared. The views of students and lecturers differed significantly on the extent of changes which were made to teaching practices and the setting of examination papers. The article identified aspects to be considered to encourage students' deep learning, long term retention, selection of knowledge and preparation for openbook assessment. Issues lecturers need to take into account when determining their teaching and assessment approach within the broader context of an open-book assessment environment were also identified.

Keywords: learning, testing effect, constructive alignment, competency-based education, knowledge management, SAICA, IRBA, open-book assessment, accounting education

\section{INTRODUCTION}

Biggs (1996) describes teaching as "a complex system embracing, at the classroom level, teacher, students, the teaching context, student learning activities, and the outcome", which is then "nested within the larger institutional system". It is contended that the components of the system should be constructively aligned to achieve the desired results (Biggs 1996). This is the theory of constructive alignment and implies that teaching practices should be adopted to 
complement new assessment methods.

A new assessment method was introduced by the Independent Regulatory Board of Auditors (IRBA) and the South African Institute of Chartered Accountants (SAICA) by changing their respective qualifying examinations from a closed-book assessment (CBA) to an open-book assessment (OBA). Accredited training institutions followed suit by changing their examinations to the same format for final-year students. Research showed that students adjusted their learning behaviour as a result of the altered approach in assessment (Kruger 2011). Changes in the learning behaviour of students have also been found in other studies following the introduction of OBA (Koutselini-Ioannidou 1997; Boniface 1985; Baillie and Toohey 1997).

Following an extensive systematic review, Durning et al. (2016) concluded that empirical literature comparing OBA to CBA is fairly limited. Only a few studies comparing OBA to CBA in accounting education could be found. Rowlands and Forsyth (2006) focused on the rationale of distinguishing between embedded and non-embedded knowledge in OBA in professional accountancy examinations. (Kruger 2011) investigated how accountancy students and lecturers perceived the change in their learning behaviour due to the introduction of OBA. Du Preez (2012) researched taxation students' perceptions before being exposed to OBA, and subsequently compared it with their perceptions after being exposed to OBA (Du Preez 2015). Following Biggs's (1996) theory on constructive alignment, accounting academics faced a new challenge to align their teaching with this new method of assessment.

\section{RESEARCH PROBLEM}

The primary research problem identified is to determine whether the introduction of OBA has changed students' and lecturers' approaches to teaching and assessment at departments of accountancy at South African universities.

In order to address the primary research problem, the following secondary research problems are posed:

- What are students' perceptions regarding the appropriateness of OBA to assess knowledge in the context of rapid knowledge expansion;

- Do students perceive that they receive enhanced education as a result of the introduction of OBA?

- Do students perceive a change in the setting of questions (assessments) as a result of the introduction of OBA? 


\section{RESEARCH OBJECTIVES AND METHODOLOGY}

In order to address the secondary research problems, and, the primary research problem, research objectives identified for this study were:

- To determine students' perceptions on whether their prior university education had adequately prepared them for OBA.

- To determine the perceptions of students and lecturers on whether OBA resulted in tests, examinations and assignments that were more appropriate to assess students' knowledge.

- To determine the perceptions of students and lecturers on whether OBA is superior to CBA in addressing the ever-increasing demands made by society on professionally qualified graduandi to have access to information and to be able to use it meaningfully in an age of rapid knowledge expansion.

- $\quad$ To determine the perceptions of students on whether they received enhanced teaching as a result of OBA.

- To compare the perceptions of lecturers and students on whether lecturers changed their approach to teaching and assessment in terms of OBA compared to when assessment was done through CBA.

Two supporting objectives of the study were:

- To determine whether there are significant differences in the perceptions regarding the above issues between of a number of homogenous groups based on gender, first language, second language and language of tuition.

- To identify issues lecturers need to take into account when determining their teaching and assessment approach within the broader context of an OBA environment.

An extensive study of existing literature informed an empirical study, by means of a questionnaire, among a selected population of prospective chartered accountants at the departments of accountancy of a number of South African universities.

\section{LITERATURE STUDY}

The literature study investigates certain relevant issues that have to be considered when the method of assessment is changed from CBA to OBA. The issues include competency-based education and the development of students' pervasive skills; deep learning, long term retention 
and students' preferences regarding assessment; the testing effect; constructive alignment; and student preparation and assessment in an OBA environment.

\section{Competency-based education and the development of pervasive skills}

Whereas content knowledge becomes dated and is not always transferable across different fields of business, critical skills which rarely become obsolete are more readily transferable between careers (French and Coppage 2003). OBA is seen as a way to better prepare professionals for the competency of handling large amounts of information (Heijne-Penninga et al. 2011; IRBA 2004; Feldhusen 1961) with greater emphasis on the development of competencies and pervasive skills (Rust 2002). Students also reported that they had used a more holistic approach by making broader connections in an OBA environment compared to a CBA environment (Karagiannopoulou 2010). Importantly, accounting students perceived that they mastered more work in an OBA environment compared to a CBA environment (Kruger 2011).

The international regulatory framework in which accountants operate has increased significantly in complexity over the past 25 years and has placed considerable pressure on accounting courses (Scully and Kerr 2014). This crisis of information overload in accounting education necessitates change in what and how students are taught (Turner, Reed and Greiman 2011).

Lecturers should constantly assess whether their teaching approach contributes to developing lifelong learners (Breton 1999). Students often have the expectation that lecturers will provide them with summaries, mind maps and other resources to master the content of their courses. Scott, Buchanan and Haigh (1997) remark that some students "wish to be 'filled up' with ideas and skills, which they believe can be used as recipes for responding to situations in the future". This material becomes their primary source for preparing for examinations, without their having to pay too much attention to the sources (such as legislation, standards and text books). Teaching methods should include the encouragement of students to engage more with this source material, as it will be the students' source of new information when practising as accountants.

It was found at certain South African Universities' departments of accountancy that there was adequate development of technical accounting and external reporting skills, but that the development of pervasive skills was deficient (Smit and Steenkamp 2015). It is therefore important that accounting educators take cognisance of the importance of developing the pervasive skill of knowledge management and the related skill of life-long learning in an OBA environment. This might also contribute to deep learning and long term knowledge retention. 


\section{Deep learning, knowledge retention and students' preferences}

Concerns regarding weaknesses in South African accounting students' deep thinking and problem-solving abilities are discussed in a study on learning styles of students (Visser and Vreken 2006). This concern is echoed by Ballantine and McCourt Larres (2009), who state that accounting education "has been criticised for its narrow focus and emphasis on mechanical procedural approaches".

A deep learning approach can be defined as: "[T]he student attempts to make sense of what is to be learnt, which consists of ideas and concepts [and] involves [the student in] thinking, seeking integration between components and between tasks, and 'playing' with ideas" (Rust 2002). Some earlier studies on OBA suggest that it encourages deeper learning (Theophilides and Dionysiou 1996; Theophilides and Koutselini 2000).

However, Heijne-Penninga, Kuks, Schönrock-Adema, Snijders, and Cohen-Schotanus (2008), found the opposite. A deep information processing questionnaire developed in 1996, which covered three deep learning dimensions, namely critical reading (understanding); broaden one's context (elaboration), and structuring (analysis) found that students adopted a deeper approach for the closed-book tests than for the open-book tests (Heijne-Penninga et al. 2008). Other studies found that students assessed by way of open-book tests, performed more poorly in delayed retention tests compared to those who prepared for initial closed-book tests. (Moore and Jensen 2007; Agarwal and Roediger 2011). And while many would assume that all students will prefer an open-book examination over a closed-book examination as testing aids provide a "crutch" during open-book examinations (Larwin 2012), this is not always the case. One study found that students who preferred OBA over CBA, all reported that they followed a deep approach. Those who preferred CBA indicated that they did not use a deep approach or that they strategically shifted their approach depending on the type of examination. (Karagiannopoulou 2010).

Notwithstanding this, Heijne-Penninga et al., (2008) argue that the concept of deep learning should be reinvestigated given the change in type of students and the importance of the skill of finding and selecting relevant knowledge at a specific moment. Furthermore, students might improve their learning strategies and retrieval of knowledge through regular self-testing (Karpicke, Butler and Roediger 2009).

\section{The testing effect}

Researchers found that free-recall testing even without feedback (or self-testing) improved long-term retention significantly more than repeated studying. Repeated studying improved short-term retention more than testing, causing students to predict that repeated studying would 
lead to better long-term retention (Roediger and Karpicke 2006). Students tend to employ repeated studying more than practising retrieval and can "fall prey to illusions of competence and believe that they know the material better than they actually do" (Roediger and Karpicke 2006). This is called the testing effect, and also holds true for open-book tests. Studies where OBA was compared with CBA also demonstrated testing effects that were roughly similar (Pauker 1974; Agarwal et al. 2008; Gharib, Phillips and Mathew 2012).

However, accounting students indicated that they did less memorising and instead worked through questions when preparing for an OBA compared to a CBA (Author). Given how effective the practice of retrieval for long-term retention is, students should be encouraged to test their own knowledge under test conditions. OBA can encourage this behaviour by placing less pressure on students to memorise information. In addition to this, the backwash effect indicates that assessment drives both learning and teaching, confirming the importance of the theory of constructive alignment (Biggs 1996).

\section{Constructive alignment}

By changing the way of assessment, learning and teaching can be moved in the desired direction. Even if curriculum objectives nominate higher cognitive level activities, the backwash from testing will lead to equilibrium being achieved at a lower level if the set assessment tasks address lower ones. To enhance teaching, all components of the system need to be addressed to be successful (Biggs 1996). Healy, McCutcheon, and Doran (2014) remarks that assessment activities requiring memory and reproduction will not produce the benefits of critical thinking for students.

Need for cognition was found to be pivotal for success in both OBA and CBA. Although the need for cognition in students is partly related to personality and IQ level, it can be changed and developed over time, among others by presenting students with complex problems (HeijnePenninga et al. 2010). Using a problem-based teaching approach with both OBA and CBA, as opposed to a conventional teaching approach, led to better long-term retention among students. (Heijne-Penninga 2013).

In the South African context, the focus of universities on the success of their students in the qualifying examination of SAICA often happens at the expense of the ability of students to develop inquisitive minds by doing research and reading more widely. The SAICA syllabus does not require research skills to be learnt. Consequently research skills are not taught in the postgraduate curricula of accredited universities (Lubbe 2013). This is unfortunate as "research requires students to gather, examine and interpret information and ideas critically before using them to build logical arguments and these academic capacities mirror the professional skills 
required by SAICA and prospective employers" (Hesketh 2011). It can be argued that OBA might be utilised more effectively to foster a research culture in the teaching-learning environment. Instead of focusing on designing a learning environment that helps students to memorise, properly designed OBA can encourage students to consult various sources and then to integrate this information (Theophilides and Dionysiou 1996).

\section{Preparing students for OBA}

In an extended study (Eilertsen and Valdermo 2000), there was a greater acceptance of OBA among students who were exposed to a rich variety of learning methods such as group work, projects and excursions. These methods were also found to encourage meta-cognitive development i.e. making students more aware of how and at which level they were thinking. When students are introduced to OBA it is important that they be prepared for this method of assessment (Boniface 1985; Koutselini-Ioannidou 1997). Students tend to underestimate how well they have to prepare for an open-book examination, leading to students not following a deep learning approach, and a reduced study effort.

\section{Assessment}

Many researchers investigating OBA report that setting questions for OBA is challenging for lecturers (Tussing 1951; Betteridge 1971; Croasdale 1973; Eilertsen and Valdermo 2000; Shine, Kiravu and Astley 2004). Compared to closed-book examinations, open-book examinations should emphasise reasoning and problem solving rather than recall (Tussing 1951; Kalish 1958; Feldhusen 1961; Krarup, Naeraa and Olsen 1974).

While it can be argued that decision making in the workplace is essentially an open-book activity (Green, Ferrante and Heppard 2016), it does make sense that professionals should have a level of core knowledge (Heijne-Penninga et al. 2008) to function effectively in the work place. It is not realistic to expect that professional accountants should have memorised all information necessary to deal with all situations they are likely to encounter in practice. A distinction can be made between knowledge that should be embedded (memorised) and not embedded. It is in assessing candidates' ability to apply this skill of accessing relevant information that OBA becomes more appropriate (Rowlands and Forsyth 2006).

Heijne-Penninga et al. (2008) used open-book examinations to assess students' ability to apply non-core knowledge but employed closed-book tests to assess core knowledge. In the accountancy examinations a "limited access, limited time" model is used to provide for assessment of both embedded and non-embedded knowledge in the same examination paper. The implication is that examiners should, in setting open-book exams through the allocation of 
marks, not allow retrieval time for embedded knowledge and allow time to refer to texts for non-embedded knowledge (Rowlands and Forsyth 2006). Consequently, successful time management in open-book examinations was identified as pivotal to success for taxation students (Du Preez 2015).

When the judgement of examiners and perceptions of students were tested as to whether embedded or non-embedded knowledge was being assessed, they found substantial differences regarding embedded knowledge, but to a much lesser extent with regard to non-embedded knowledge (Rowlands and Forsyth 2006). Thus, it is important that differences in perceptions of students and lecturers (examiners) need to be identified and addressed. The empirical study reported in the next section attempted to address such differences in perceptions.

\section{QUESTIONNAIRE DESIGN, DATA COLLECTION, SUBJECTS, DEMOGRAPHICS AND DATA ANALYSIS}

\section{Questionnaire design and data collection}

Respondents had to provide demographic information at the start of the questionnaire. In the second part students and lecturers were asked to react to the following statements, for which they had to provide scaled $(1=$ no or insignificant; $5=$ yes or significant $)$ responses per subject (Questions addressed to students and lecturers differed slightly, as indicated):

- Students: "Indicate whether you received any coaching regarding the open-book exam approach or whether you were taught the best technique when preparing for an open-book exam".

Lecturers: "Have you given coaching regarding the approach or taught the best technique to students to employ when preparing for an open-book exam?"

- Students: "Indicate whether lecturers adapted or changed their approach to teaching after the implementation of the open-book assessment policy".

Lecturers: "Did you adapt or change your approach to teaching after the implementation of the open-book assessment policy?"

- Students: "Indicate whether lecturers adapted their approach to setting questions after the implementation of the open-book assessment policy".

Lecturers: "Did you adapt your approach to setting questions after the implementation of the open-book assessment policy?" 
General statements were also made where the students and lecturers had to indicate their agreement on a 5-point Likert scale where 1 represented "disagree totally" and 5 represented "totally agree":

- 'OBA resulted in tests, exams and assignments being more appropriate to assess students' knowledge".

- "OBA is a better means than CBA of addressing the ever-increasing demands made by society on professionals to have access to information and to be able to use it meaningfully in an age of rapid knowledge expansion".

- "Students received enhanced education as a result of OBA".

The following general question requiring a yes/no response was put to the students:

- "Do you believe that your previous university education adequately prepared you adequately to write an exam for which an open-book policy has been implemented?"

Pilot testing of the questionnaires was done by having three academic clerks, who completed their studies the previous year and three academics complete the questionnaires before it was distributed to the various Universities. The questionnaires were completed manually and anonymously by the students during class time under supervision of a lecturer. The questionnaires were sent by e-mail to lecturers as a spreadsheet document which they completed and e-mailed back to the author. The data collected from lecturers were anonymised before analysis. The questionnaire presented to the lecturers also provided space for comments.

\section{Subjects}

The students who participated in the survey were accounting graduates and were registered for a post graduate course to acquire the Certificate in Theory of Accounting (CTA). SAICA requires candidates to have a CTA for admittance to their centrally administered initial test of competence examination (ITC). Universities or other institutions need to be accredited by SAICA to be able to award the CTA. The subject matter of the CTA courses is similar to that of the ITC, which all candidates write simultaneously. Students who receive a CTA from a SAICA accredited institution will qualify to write the ITC in the first quarter of the next year. The lecturers who participated in the survey were employed at a department of accountancy of one of seven full-time universities. 


\section{Demographics}

In total there were 2185 final year accounting students enrolled at accredited full-time universities. The seven targeted full-time universities had a total of 1490 registered students, of which $1065(71 \%)$ completed the questionnaires. The study participants therefore constituted 49 per cent of the population of full-time CTA students. Fifty-nine of the 252 academics $(23 \%)$ at the departments of accountancy partaking in the study completed questionnaires. Most of them were registered members of SAICA.

Ninety-two per cent of the students had been exposed to at least four open-book assessments in the year during which the survey was done, while they were mostly assessed in closed-book settings as undergraduate students. As a result the students were able to compare the respective methods of assessment.

Forty-five percent of students were male and 55 per cent female; 42 per cent were taught in Afrikaans and the rest in English. As far as first languages were concerned, 46 per cent of students were Afrikaans-speaking, 38 per cent spoke English and 16 per cent indicated "other languages" as being their first language.

\section{Data analysis}

The aggregate standard deviation and mean score were calculated for the responses of the students and lecturers. A Kruskal-Wallis test was performed to test for statistically significant differences between first language groups, as more than two groups applied. To determine whether there were statistically significant differences between the perceptions of students and lecturers, a Man-Whitney U-test was performed. For differences within homogenous groups only those that were statistically significant were reported.

For the questions on coaching on how to prepare, change in approach to teaching and change in setting questions, the average of all the responses of the students per subject was calculated and then compared to the response of lecturers as the lecturers did not respond to these statements per subject. Cronbach's alphas for the student's responses were calculated which were above 0.7 proving sufficient reliability.

\section{RESULTS}

Table 1: Means, Standard Deviations and P-Values of responses

\begin{tabular}{|l|c|c|c|c|c|}
\hline & $\begin{array}{c}\text { Student } \\
\text { Mean }\end{array}$ & $\begin{array}{c}\text { Standard } \\
\text { Deviation }\end{array}$ & $\begin{array}{c}\text { Lecturer } \\
\text { Mean }\end{array}$ & $\begin{array}{c}\text { Standard } \\
\text { Deviation }\end{array}$ & $\begin{array}{c}\mathbf{P} \\
\text { Value }\end{array}$ \\
\hline $\begin{array}{l}\text { OBA is more appropriate to assess students' } \\
\text { knowledge }\end{array}$ & 3.54 & $(1.14)$ & 3.25 & $(1.14)$ & 0.11 \\
\hline $\begin{array}{l}\text { OBA is better to address societal demands on } \\
\text { professionals to use expanding knowledge }\end{array}$ & 4.06 & $(1.05)$ & 3.81 & $(0.91)$ & 0.02 \\
\hline $\begin{array}{l}\text { Students received better and more useful } \\
\text { education due to OBA }\end{array}$ & 3.33 & $(1.24)$ & 2.96 & $(1.12)$ & 0.03 \\
\hline
\end{tabular}




\begin{tabular}{|c|c|c|c|c|c|}
\hline & $\begin{array}{c}\text { Student } \\
\text { Mean }\end{array}$ & $\begin{array}{l}\text { Standard } \\
\text { Deviation }\end{array}$ & $\begin{array}{c}\text { Lecturer } \\
\text { Mean }\end{array}$ & $\begin{array}{l}\text { Standard } \\
\text { Deviation }\end{array}$ & $\begin{array}{c}P \\
\text { Value }\end{array}$ \\
\hline \multicolumn{6}{|c|}{ Received/gave coaching on how to prepare for: } \\
\hline Financial Accounting & 2.59 & $(1.19)$ & & & \\
\hline Auditing & 2.44 & $(1.20)$ & & & \\
\hline Taxation & 2.94 & $(1.30)$ & & & \\
\hline Management Accounting & 2.13 & $(1.20)$ & & & \\
\hline Average & 2.52 & $(0.99)$ & 2.76 & $(1.15)$ & 0.23 \\
\hline \multicolumn{6}{|c|}{ Lecturers adapted or changed approach to teaching for: } \\
\hline Financial Accounting & 1.86 & $(1.11)$ & & & \\
\hline Auditing & 1.87 & $(1.13)$ & & & \\
\hline Taxation & 2.03 & $(1.23)$ & & & \\
\hline Management Accounting & 1.62 & $(0.98)$ & & & \\
\hline Average & 1.85 & $(0.97)$ & 2.96 & $(1.20)$ & $<.01$ \\
\hline \multicolumn{6}{|c|}{ Lecturers adapted approach to setting questions for: } \\
\hline Financial Accounting & 2.59 & $(1.38)$ & & & \\
\hline Auditing & 2.61 & $(1.36)$ & & & \\
\hline Taxation & 2.53 & $(1.34)$ & & & \\
\hline Management Accounting & 2.24 & $(1.32)$ & & & \\
\hline Average & 2.49 & $(1.22)$ & 3.63 & $(1.18)$ & $<.01$ \\
\hline
\end{tabular}

Table 2: Summary of responses

\begin{tabular}{|c|c|c|c|c|c|c|}
\hline & \multicolumn{2}{|c|}{ Disagree } & \multirow{2}{*}{$\frac{\text { Neutral }}{3}$} & \multicolumn{2}{|c|}{ Agree } \\
\hline & & 1 & 2 & & 4 & 5 \\
\hline \multirow{4}{*}{$\begin{array}{l}\text { More appropriate to assess } \\
\text { students' knowledge }\end{array}$} & \multirow{2}{*}{ Students } & $5 \%$ & $12 \%$ & $32 \%$ & $30 \%$ & $21 \%$ \\
\hline & & \multicolumn{2}{|c|}{$17 \%$} & & \multicolumn{2}{|c|}{$51 \%$} \\
\hline & \multirow{2}{*}{ Lecturers } & $11 \%$ & $11 \%$ & $29 \%$ & $40 \%$ & $9 \%$ \\
\hline & & \multicolumn{2}{|c|}{$22 \%$} & & \multicolumn{2}{|c|}{$49 \%$} \\
\hline \multirow{4}{*}{$\begin{array}{l}\text { Better to address the societal } \\
\text { demands on professionals to use } \\
\text { expanding knowledge }\end{array}$} & \multirow{2}{*}{ Students } & $3 \%$ & $4 \%$ & $19 \%$ & $34 \%$ & $40 \%$ \\
\hline & & \multicolumn{2}{|c|}{$7 \%$} & & \multicolumn{2}{|c|}{$74 \%$} \\
\hline & \multirow{2}{*}{ Lecturers } & $4 \%$ & $4 \%$ & $17 \%$ & $56 \%$ & $19 \%$ \\
\hline & & \multicolumn{2}{|c|}{$8 \%$} & & \multicolumn{2}{|c|}{$75 \%$} \\
\hline \multirow{4}{*}{$\begin{array}{l}\text { Students received better/more } \\
\text { useful education }\end{array}$} & \multirow{2}{*}{ Students } & $10 \%$ & $13 \%$ & $33 \%$ & $25 \%$ & $19 \%$ \\
\hline & & \multicolumn{2}{|c|}{$23 \%$} & & \multicolumn{2}{|c|}{$44 \%$} \\
\hline & \multirow{2}{*}{ Lecturers } & $13 \%$ & $19 \%$ & $32 \%$ & $30 \%$ & $6 \%$ \\
\hline & & \multicolumn{2}{|c|}{$32 \%$} & & \multicolumn{2}{|c|}{$36 \%$} \\
\hline
\end{tabular}

\section{DISCUSSION}

\section{Adequacy of previous education}

Sixty-one percent of respondents felt that their prior university education prepared them adequately for OBA. Notwithstanding this, as many as 39 per cent felt their education was inadequate. The fact that these students did not have any exposure to OBA before their final year of study could have contributed to the large number indicating that their education was inadequate. 


\section{Appropriateness of OBA to assess students' knowledge and whether OBA is better to address societal demands on professionals to use expanding knowledge}

Most students (3.54 mean) and lecturers (3.25 mean) seemed to agree that OBA resulted in tests, exams and assignments to be more appropriate to assess students' knowledge. Students (4.06 mean) and lecturers (3.81 mean) agreed strongly that OBA was a better means than CBA of addressing the ever-increasing demands made by society on professionals to have access to information and to be able to use it meaningfully in an age of rapid knowledge expansion. There however was a statistically significant difference in their level of agreement ( $p$-value $=0.02$ ).

These findings confirm agreement among researchers that OBA is helpful to develop the pervasive skill of knowledge management (Heijne-Penninga et al. 2011; Feldhusen 1961; Maharg 1999).

\section{Quality of education and change in approach to teaching}

There was greater agreement between students (3.33 mean) that they received enhanced education with OBA compared to lecturers (2.96 mean). The difference was also statistically significant $(p$-value $=0.03)$.

The combined mean (2.53) for students was less than that of lecturers (2.76) on how much coaching took place on how to prepare for open-book exams. The students' mean was the highest for taxation (2.96) and the lowest for management accounting (2.14).

There is a significant difference between the opinion of students (overall mean of 1.85) and lecturers (2.96 mean) on the extent to which lecturers changed the way they taught with a p-value of less than 0.01. According to the students, the greatest change happened for taxation (2.03 mean) and the least for management accounting (1.62 mean). Around half of the students perceived no change for financial accounting, auditing and taxation, with 64 per cent of students perceiving no change for management accounting.

Eilertsen and Valdermo (2000) state that a rich variety of teaching methods in an OBA environment can facilitate meta-cognitive development. If accountancy lecturers are more deliberate in communicating to students at which level work is being presented and what level of thinking is required to be successful in assessment tasks, this perception gap can potentially be closed.

\section{Setting questions}

There is a significant difference between the opinion of students (overall mean of 2.49) and lecturers (3.63 mean) on the extent to which lecturers changed the way they set questions for 
open-book examinations, with a p-value of less than 0.01 . According to the students, most change occurred in auditing (2.61 mean) and least in management accounting (2.24 mean). The difference between the mean for auditing (2.61), financial accounting (2.59) and taxation (2.53) was very small. More than 50 per cent of students chose 1 or 2 on the Likert scale, while only 18 per cent of lecturers chose 1 or 2 .

In this instance, the views of lecturers were probably more reliable, as they would be the best judges of how they set questions. This is confirmed by the following comments made by lecturers:

"Especially applicable to theoretical questions: students do not earn marks for transcribing theory directly from the standard, but for the application of the theory."

"Questions focus more on testing insight and application of theoretical knowledge than just testing the theory itself."

"An open-book exam puts pressure on students to apply their knowledge; there should be very few marks for knowledge, which makes it more difficult."

It seems that OBA in general caused lecturers to move even further away from testing lowerorder learning. This confirms the view of Rowlands and Forsyth (2006) that CTA tests and examinations have always assessed higher-order thinking skills of students; also when they were assessed using a closed-book format (Rowlands and Forsyth 2006).

\section{Significant differences in perceptions between students and lecturers}

Accounting academics must take cognisance of the significant difference in perceptions as far as changes in teaching and setting of questions is concerned. Gaps between assumptions of lecturers and perceptions of students have also been found in other studies (Steenkamp, Baard and Frick 2009). Furthermore, researchers agree that it is important that lecturers close these gaps. When lecturers' and students' perceptions of what factors contribute to student success are incongruent, it can lead to a suboptimal learning environment (Fraser and Killen 2003). Misunderstanding between students and lecturers can lead to impaired relationships which can have a negative impact on the learning environment (Van der Merwe, Van Zyl, Nel and Joubert 2014).

Mulliner and Tucker (2017) also found significant differences in perceptions of lecturers and their students regarding feedback on assessment. They propose dialogue between students and lecturers on assessment and feedback and the early involvement of students in assessment activities to reduce these conflicting perceptions.

The finding of Rowlands and Forsyth (2006) of substantial differences between the 
perceptions of accountancy students and lecturers on whether embedded or non-embedded knowledge was being assessed, strengthens the argument for dialogue between students and lecturers about assessment. Given the time constraints in open-book accountancy exams (Du Preez 2015) it is important for students to prepare in the appropriate way, especially with regards to embedding the required knowledge. Lecturers need to give guidance in this regard.

\section{Difference between subjects}

The fact that students and lecturers perceive the biggest change in the learning environment to be in Taxation and the least in Management Accounting is not surprising. The allowed texts only applied in a limited way to the management accounting syllabus and only indirectly where integrated questions required the application of knowledge of other disciplines, such as taxation, financial accounting and the companies' act. This can explain why 64 per cent of students perceived no change in the approach to the teaching of management accounting.

\section{Gender}

Some studies found that male and female students perform differently when certain assessment methods are applied (Arthur and Everaert 2012; Fallan and Opstad 2014). The statistically significant differences in the responses of male and female students are presented in Table 3 .

Table 3: Significant gender differences

\begin{tabular}{|l|c|c|c|c|c|}
\hline & $\begin{array}{c}\text { Male } \\
\text { Mean }\end{array}$ & $\begin{array}{c}\text { Standard } \\
\text { Deviation }\end{array}$ & $\begin{array}{c}\text { Female } \\
\text { Mean }\end{array}$ & $\begin{array}{c}\text { Standard } \\
\text { Deviation }\end{array}$ & $\begin{array}{c}\mathbf{P} \\
\text { Value }\end{array}$ \\
\hline Received coaching on how to prepare & & & & & \\
\hline Taxation & 2.88 & $(1.27)$ & 3.14 & $(1.27)$ & $<.01$ \\
\hline $\begin{array}{l}\text { Lecturers adapted their approach to setting } \\
\text { questions }\end{array}$ & & & & & \\
\hline Financial Accounting & 2.74 & $(1.40)$ & 2.52 & $(1.36)$ & 0.02 \\
\hline Auditing & 2.69 & $(1.35)$ & 2.46 & $(1.34)$ & 0.01 \\
\hline Taxation & 2.69 & $(1.37)$ & 2.46 & $(1.31)$ & 0.02 \\
\hline Management Accounting & 2.37 & $(1.35)$ & 2.16 & $(1.29)$ & 0.02 \\
\hline
\end{tabular}

Female students perceived that they had received significantly more coaching on how to prepare for taxation compared to male students. Male students, on the other hand, perceived that lecturers had made greater adaptations in their approach to setting questions for all four subjects compared to female students. These gender-based differences in perceptions on OBA should be researched further to arrive at more meaningful conclusions.

\section{Language}

Owing to the fact that most of the allowed texts were only available in English, many students 
with a different first language had to use texts which were written in their second or third language. Studying in a language other than their first language can have a negative impact on the learning of students (Watty, Jackson and Yu 2010). Some South African studies have found differences between perceptions on learning of students based on their first language (Stainbank 2010; Steenkamp, Baard and Frick 2009). The significant statistical differences based on first language and languages of tuition are presented in Tables 4 and 5, respectively.

Table 4: Responses of students according to first language

\begin{tabular}{|c|c|c|c|c|c|c|}
\hline & $\begin{array}{c}\text { Afrikaans } \\
\text { Mean }\end{array}$ & $\begin{array}{l}\text { Standard } \\
\text { Deviation }\end{array}$ & $\begin{array}{c}\text { English } \\
\text { Mean }\end{array}$ & $\begin{array}{l}\text { Standard } \\
\text { Deviation }\end{array}$ & $\begin{array}{l}\text { Other } \\
\text { Mean }\end{array}$ & $\begin{array}{l}\text { Standard } \\
\text { Deviation }\end{array}$ \\
\hline \multicolumn{7}{|c|}{ Better to address the societal demands on professionals to use expanding knowledge } \\
\hline & $4.06 \mathrm{ab}$ & $(0.96)$ & $4.09^{a}$ & $(1.04)$ & $3.83^{b}$ & $(1.16)$ \\
\hline \multicolumn{7}{|c|}{ Received coaching on how to prepare for: } \\
\hline Fin Accounting & $2.45^{\mathrm{a}}$ & $(1.15)$ & $2.63^{\mathrm{ab}}$ & $(1.13)$ & $2.85^{b}$ & $(1.38)$ \\
\hline Auditing & $2.39^{a}$ & $(1.17)$ & $2.37^{a}$ & $(1.11)$ & $2.72^{\mathrm{b}}$ & $(1.41)$ \\
\hline Man Accounting & $2.06^{a}$ & $(1.13)$ & $2.11^{\mathrm{ab}}$ & $(1.17)$ & $2.36^{\mathrm{b}}$ & $(1.42)$ \\
\hline \multicolumn{7}{|c|}{ Lecturers adapted/changed their approach to teaching for: } \\
\hline Auditing & $1.82^{\mathrm{a}}$ & $(1.09)$ & $1.83^{\mathrm{ab}}$ & $(1.07)$ & $2.09^{b}$ & $(1.34)$ \\
\hline Man Accounting & $1.55^{\mathrm{a}}$ & $(0.89)$ & $1.58^{\mathrm{a}}$ & $(0.91)$ & $1.89^{\mathrm{b}}$ & $(1.27)$ \\
\hline \multicolumn{7}{|c|}{ Lecturers adapted their approach to setting questions for: } \\
\hline Fin Accounting & $2.38^{a}$ & $(1.29)$ & $2.62^{\mathrm{b}}$ & $(1.35)$ & $3.09^{c}$ & $(1.52)$ \\
\hline Auditing & $2.37^{a}$ & $(1.28)$ & $2.68^{b}$ & $(1.33)$ & $3.10^{c}$ & $(1.50)$ \\
\hline Taxation & $2.40^{\mathrm{a}}$ & $(1.27)$ & $2.49^{a}$ & $(1.31)$ & $2.97^{b}$ & $(1.50)$ \\
\hline Man Accounting & $2.04^{a}$ & $(1.20)$ & $2.26^{a}$ & $(1.27)$ & $2.74^{b}$ & $(1.56)$ \\
\hline
\end{tabular}

Means containing the same superscript $\left({ }^{a},{ }^{b}\right.$ or $\left.{ }^{c}\right)$ are not significantly different.

Table 5: Responses of students according to language of course presentation

\begin{tabular}{|l|c|c|c|c|c|}
\hline & $\begin{array}{c}\text { Afrikaans } \\
\text { Mean }\end{array}$ & $\begin{array}{c}\text { Standard } \\
\text { Deviation }\end{array}$ & $\begin{array}{c}\text { English } \\
\text { Mean }\end{array}$ & $\begin{array}{c}\text { Standard } \\
\text { Deviation }\end{array}$ & $\begin{array}{c}\text { P } \\
\text { Value }\end{array}$ \\
\hline Received coaching on how to prepare for: \\
\hline Financial Accounting & 2.36 & $(1.12)$ & 2.75 & $(1.21)$ & $<.01$ \\
\hline Lecturers adapted/changed their approach to teaching for: \\
\hline Financial Accounting & 1.74 & $(1.01)$ & 1.95 & $(1.16)$ & 0.03 \\
\hline Auditing & 1.76 & $(1.05)$ & 1.95 & $(1.17)$ & 0.04 \\
\hline Lecturers adapted their approach to setting questions for: & & $(1.41)$ & $<.01$ \\
\hline Financial Accounting & 2.32 & $(1.28)$ & 2.77 & $(1.39)$ & $<.01$ \\
\hline Auditing & 2.22 & $(1.22)$ & 2.89 & $(1.37)$ & $<.01$ \\
\hline Taxation & 2.34 & $(1.26)$ & 2.66 & $(1.37)$ & $<.01$ \\
\hline Management Accounting & 1.99 & $(1.18)$ & 2.41 & & \\
\hline
\end{tabular}

When considering the statistically significant differences relating to first language for responses in Table 4, English-speaking students in general showed stronger agreement than Afrikaansspeaking students, while students with first languages categorised as "other" showed stronger agreement than English-speaking students.

When considering the statistically significant differences relating to language of tuition for responses in Table 5, students who received tuition in English in general showed stronger agreement than students who received tuition in Afrikaans. 
The significant differences in perceptions based on first language and language of tuition warrants further research. The fact that most of the allowed texts were only available in English could have had an impact on the perceptions of students.

\section{CONCLUSION}

OBA has been applied for more than 10 years now by SAICA and SAICA-accredited universities and it may be assumed that that this method of assessment is here to stay. This article investigated perceived changes in teaching and assessment under OBA compared to CBA by means of an empirical study. Prior to this investigation, a literature study of a number of relevant issues that have to be considered when the method of assessment is changed from CBA to OBA was performed. The issues included competency-based education and the development of students' pervasive skills; deep learning, long term retention and students' preferences regarding assessment; the testing effect; constructive alignment; and student preparation and assessment in an OBA environment.

The literature study elucidated aspects that accounting academics need to consider when designing their teaching practices. OBA offers the opportunity to enhance the competencies of knowledge management and lifelong learning which are growing in importance in the knowledge economy. Although OBA on its own does not promote deeper learning, many studies have concluded that OBA contributes to deeper learning. Moreover, some studies found that it can lead students not to employ a deeper approach to learning compared to CBA, especially when introduced to OBA for the first time. It is therefore imperative that, for OBA especially, teaching strategies be designed to combat negative learning behaviour. A teaching environment that presents students with complex unstructured problems which they have to solve as active learners, for instance using problem-based learning, can contribute to reaching this goal. It remains important that for any method of assessment to contribute to deeper learning that the whole system of teaching, learning and assessment be constructively aligned.

Accounting academics need to take cognisance of the benefits of the testing effect on long-term retention and to encourage students to practise retrieval as part of their learning activities. OBA can contribute in this regard as there is less pressure on students to memorise and they can therefore free up preparation time to practise retrieval.

It is essential that assessment tasks are at higher taxonomical levels in an OBA environment and that students are specifically prepared for OBA. In setting question papers, lecturers need to take cognisance of the difference between embedded and non-embedded knowledge and take this into account in determining the time given to complete assessments. Using separate closed-book tests to assess core knowledge and open-book tests to assess back- 
up knowledge might also be a solution.

The empirical investigation found that the majority of students perceived that their previous university education had adequately prepared them to write an examination for which an open-book policy had been implemented. Students and lecturers also believe that OBA resulted in tests, examinations and assignments that were more appropriate to assess students' knowledge. Students and lecturers agreed strongly that OBA was a better means than CA of addressing the ever-increasing demands made by society on professionals to have access to information and to be able to use it meaningfully in an age of rapid knowledge expansion. There was also agreement between students and lecturers that students received enhanced education with OBA. The level of agreement differed significantly with students showing stronger agreement than lecturers. There has been a perceived change in teaching practices and how questions are set for OBA compared to CBA. However, the majority of students perceived no substantial change. There were statistically significant differences between the perceptions of students and lecturers on the extent to which changes took place in teaching and the setting of questions.

The introduction of OBA had a different effect on different subjects. Students and lecturers perceived that the biggest change in the teaching/learning environment happened for taxation and the least for management accounting. This study also found statistically significant differences in some of the responses depending on the gender, first language and language of tuition.

\section{REFERENCES}

Agarwal, P. K., J. D. Karpicke, S. H. K. Kang, H. L. Roediger and K. B. McDermott. 2008. Examining the testing effect with open- and closed-book tests. Applied Cognitive Psychology 22: 861-876.

Agarwal, P. K. and H. L. Roediger. 2011. Expectancy of an open-book test decreases performance on a delayed closed-book test. Memory 19(8): 836-852.

Arthur, N. and P. Everaert. 2012. Gender and performance in accounting examinations: Exploring the impact of examination format. Accounting Education 21(5): 471-487.

Baillie, C. and S. Toohey. 1997. The "Power Test": Its impact on student learning in a materials science course for engineering students. Assessment and Evaluation in Higher Education 22(1): 33-48.

Ballantine, J. and P. McCourt Larres. 2009. Accounting undergraduates' perceptions of cooperative learning as a model for enhancing their interpersonal and communication skills to interface successfully with professional accountancy education and training. Accounting Education 18(4 5): $387-402$.

Betteridge, D. 1971. Open-book exams. Education in Chemistry 8: 68-69.

Biggs, J. B. 1996. Enhancing teaching through constructive alignment. Higher Education 32(3): 347364.

Boniface, D. 1985. Candidate's use of notes and textbooks during an open-book examination. Educational Research 27(3): 201-209. 
Breton, G. 1999. Some empirical evidence on the superiority of the problem-based learning (PBL) method. Accounting Education 8(1): 1-12.

Croasdale, R. 1973. Open-book examinations in operational research (A personal view). International Journal of Mathematical Education in Science and Technology 4: 133-135.

Du Preez, H. 2012. Taxation students' perceptions of open-book assessment prior to the qualifying examination of South African chartered accountants. South African Journal of Accounting Research 26(1): 119-142.

Du Preez, H. 2015. Taxation students' perceptions of open-book assessment: A follow-up interactive qualitative analysis. South African Journal of Accounting Research 29(1): 84-99.

Durning, S. J., T. Dong, T. Ratcliffe, L. Schuwirth, A. R. Artino, J. R. Boulet and K. Eva. 2016. Comparing open-book and closed-book examinations. Academic Medicine 91(4): 583-599.

Eilertsen, T. V. and O. Valdermo. 2000. Open-book assessment: A contribution to improved learning? Studies in Educational Evaluation 26(2): 91-103.

Fallan, L. and L. Opstad. 2014. Beyond gender performance in accounting: Does personality distinction matter? Accounting Education 23(4): 343-361.

Feldhusen, J. F. 1961. An evaluation of college students' reactions to open-book tests. Educational and Psychological Measurement 21: 637-646.

Fraser, W. J. and R. Killen. 2003. Factors influencing academic success or failure of first-year and senior university students: Do education students and lecturers perceive things differently? South African Journal of Education 23(4): 254-263.

French, G. R. and R. E. Coppage. 2003. A strategic model for accounting education. The Journal of Applied Business Research 19(2): 107-116.

Gharib, A., W. Phillips and N. Mathew. 2012. Cheat sheet or open-book? A comparison of the effects of exam types on performance, retention, and anxiety. Psychology Research 2(8): 469-478

Green, S. G., C. J. Ferrante and K. A. Heppard. 2016. Using open-book exams to enhance student learning, performance, and motivation. The Journal of Effective Teaching 16(1): 19-35.

Healy, M., M. McCutcheon and J. Doran. 2014. Student views on assessment activities: Perspectives from their experience on an undergraduate programme. Accounting Education 23(5): 467-482.

Heijne-Penninga, M., J. B. M. Kuks, W. H. A. Hofman and J. Cohen-Schotanus. 2008. Influence of open- and closed-book tests on medical students' learning approaches. Medical Education 42(10): 967-974.

Heijne-Penninga, M., J. B. M. Kuks, J. Schönrock-Adema, T. B. Snijders and J. Cohen-Schotanus. 2008. Open-book tests to complement assessment-programmes: Analysis of open- and closedbook tests. Advances in Health Sciences Education 13(3): 263-273.

Heijne-Penninga, M., J. B. M. Kuks, W. H. A. Hofman and J. Cohen-Schotanus. 2010. Influences of deep learning, need for cognition and preparation time on open- and closed-book test performance. Medical Education 44(9): 884-891.

Heijne-Penninga, M., J. B. M. Kuks, W. H. A. Hofman and J. Cohen-Schotanus. 2011. Directing students to profound open-book test preparation: The relationship between deep learning and open-book test time. Medical Teacher 33(1): 16-21.

Heijne-Penninga, M., J. B. M. Kuks, W. H. A. Hofman, A. M. M. Muijtjens and J. Cohen-Schotanus. 2013. Influence of PBL with open-book tests on knowledge retention measured with progress tests. Advances in Health Sciences Education 18(3): 485-495.

Hesketh, J. 2011. Accounting academics' multiple challenges: Issues-driven learning offers a way forward. South African Journal of Accounting Research 25(1): 1-34.

Independent Regulatory Board of Auditors. 2004. Open-book assessment and the public practice examination (PPE). Maneo: 1-15.

IRBA, see Independent Regulatory Board of Auditors. 
Kalish, R. A. 1958. An experimental evaluation of the open book examination. Journal of Educational Psychology 49(4): 200-204.

Karagiannopoulou, E. 2010. Effects of classroom learning experiences and examination type on students' learning. Psychology 17(4): 325-342.

Karpicke, J. D., A. C. Butler and H. L. Roediger. 2009. Metacognitive strategies in student learning: Do students practise retrieval when they study on their own? Memory (Hove, England) 17(4): 471-479.

Koutselini-Ioannidou, M. 1997. Testing and life-long learning: Open-book and closed-book examination in a university course. Studies in Educational Evaluation 23(2): 131-139.

Krarup, N., N. Naeraa and C. Olsen. 1974. Open-book tests in a university course. Higher Education 3(2): $157-164$.

Kruger, S. J. 2011. Students' and lecturers' perceptions of the effect of open-book examinations on the learning behaviour of accountancy students. South African Journal of Accounting Research 25(1): 35-57.

Larwin, K. H. 2012. Student prepared testing aids: A low-tech method of encouraging student engagement. Journal of Instructional Psychology 39(2): 105.

Lubbe, I. 2013. Educating accounting professionals: Development of a theoretical framework as a language of description of accounting knowledge production and its implications for accounting academics at South African universities. South African Journal of Accounting Research 27(1): 87-124.

Maharg, P. 1999. The culture of mnemosyne: Open-book assessment and the theory and practise of legal education. International Journal of the Legal Profession 6(2): 219-239.

Moore, R. and P. A. Jensen. 2007. Do open-book exams impede long-term learning in introductory biology courses? Journal of College Science Teaching 36(7): 46-49.

Mulliner, E. and M. Tucker. 2017. Feedback on feedback practice: Perceptions of students and academics. Assessment and Evaluation in Higher Education 42(2): 266-288.

Pauker, J. D. 1974. Effect of open book examinations on test performance in an undergraduate child psychology course. Teaching Psychology 1(2): 71-73.

Roediger, H. L. and J. D. Karpicke. 2006. Test-enhanced learning: Taking memory tests improves long-term retention. Psychological Science 17(3): 249-255.

Rowlands, J. E. and D. Forsyth. 2006. Open book professional accountancy examinations. South African Journal of Higher Education 20(5): 703-717.

Rust, C. 2002. The impact of assessment on student learning. Active Learning in Higher Education 3(2): 145-158.

SAICA, see South African Institute of Chartered Accountants.

South African Institute of Chartered Accountants. 2014. Competency framework detailed guidance for the academic programme. https://www.saica.co.za/Portals/0/LearnersStudents/documents/ Detailed_Guidance_to_the_competency_framework_for_the_academic_programme_Updated and_approved_July_2014. pdf (Accessed 28 July 2016).

Scott, J., J. Buchanan and N. Haigh. 1997. Reflections on student-centred learning in a large class setting. British Journal of Educational Technology 28(1): 19-30.

Scully, G. and R. Kerr. 2014. Student workload and assessment: Strategies to manage expectations and inform curriculum development. Accounting Education 23(5): 443-466.

Shine, S., C. Kiravu and J. Astley. 2004. In defence of open-book engineering degree examinations. International Journal of Mechanical Engineering Education 32(3): 197-211.

Smit, S. and G. Steenkamp. 2015. The competencies developed in an undergraduate accounting course before SAICA's competency framework was effective: A student's perspective. Journal of Economic and Financial Sciences 8(2): 666-688. 
Stainbank, L. J. 2010. Students' perceptions of the usefulness of an accounting project in acquiring accounting knowledge and professional skills. Meditari Accountancy Research 24(1): 79-100.

Steenkamp, L. P., R. S. Baard and B. L. Frick. 2009. Factors influencing success in first-year accounting at a South African university: A comparison between lecturers' assumptions and students' perceptions. South African Journal of Accounting Research 23(1): 113-140.

Theophilides, C. and O. Dionysiou. 1996. The major functions of the open-book examination at the university level: A factor analytic study. Studies in Educational Evaluation 22(2): 157-170.

Theophilides, C. and M. Koutselini. 2000. Study behaviour in the closed-book and the open-book examination: A comparative analysis. Educational Research and Evaluation 6(4): 379-393.

Turner, K. F., R. O. Reed and J. Greiman. 2011. Accounting education in crisis. American Journal of Business Education 4(12): 39-44.

Tussing, L. 1951. A consideration of the open book examination. Educational and Psychological Measurement: 597-602.

Van der Merwe, L. J., G. J. van Zyl, M. M. Nel and G. Joubert. 2014. How we see "Y": South African health sciences students' and lecturers' perceptions of Generation Y students. African Journal of Health Professions Education 6(1): 10-16.

Visser, S. and N. Vreken. 2006. Teaching styles versus learning styles in the accounting sciences in the United Kingdom and South Africa: A comparative analysis. Meditari Accountancy Research 14(2): 97-112.

Watty, K., M. Jackson and X. Yu. 2010. Students' approaches to assessment in accounting education: The unique student perspective. Accounting Education 19(3): 219-234. 